\title{
KEANEKARAGAMAN IKAN DI SUNGAI SULUP KECAMATAN RIMBO PENGADANG KABUPATEN LEBONG PROVINSI BENGKULU
}

Pariyanto ${ }^{1 *}$, Endang Sulaiman ${ }^{2}$, Rukiah Lubis ${ }^{3}$

1,2,3Universitas Muhammadiyah Bengkulu, Jl. Bali, Kota Bengkulu, 38119, Indonesia

*Corresponding author, e-mail: pariyanto@umb.ac.id

\section{ABSTRACT}

This study aims to determine the diversity of fish species in Sulup River, Rimbo Pengadang District, Lebong Regency, Bengkulu. The Research was conducted from in April-May 2020. The method used in this study is a direct survey method. The sampling method used is purposive sampling by dividing the research station into 3 stations based on river conditions. The types of fish found in the Sulup River Rimbo Pangadang District Lebong Regency Bengkulu Province were found as many as 4 orders, 4 families with 8 species namely species Mystus singaringan, Angullia marmorata, Osteochilus vittatus, Hampala macrolepidota, Barbonymus gonionotus, Schismatorhynchos heterorhynchos, Rasbora argyrotaenia and Mastacembelus armatus. The ecological conditions in the Sulup river have a temperature of $23^{\circ} \mathrm{C}$, a depth of 1.5 $\mathrm{m}, 45 \mathrm{~cm}$ river clarity, water $\mathrm{pH} 7$, flow velocity $0.66 \mathrm{~m} / \mathrm{sec}$. Sulup River has a diversity index of 0.840 , so the diversity index is low.

Keywords: Diversity, Fish, River

\section{PENDAHULUAN}

Ikan merupakan salah satu keanekaragaman yang menyusun ekosistem sungai. Keanekaragaman hayati berperan sebagai kestabilan ekosistem (Wahyuni \& Zakaria, 2018). Keanekaragaman Ikan di Indonesia sangat banyak, diperkirakan terdapat 4.000-6.000 jenis ikan di seluruh perairan Indonesia. Tercatat 2.917 jenis ikan air tawar yang teridentifikasi di Asia Tenggara (Nurudin et al. 2013). Jumlah jenis ikan air tawar di Indonesia berdasarkan koleksi yang ada di Museum Zoologi Bogor sekitar 1.300 jenis. Hampir 40\% ikan di Asia Tenggara berada di Indonesia berbeda. Keanekaragaman jenis ikan di Indonesia cukup tinggi, ikan yang hidup di perairan Indonesia ada sekitar 4.000 jenis serta 800 jenis diantaranya hidup di air tawar dan payau. Ikan air tawar banyak dijumpai pada habitat seperti danau, sungai di pegunungan serta rawa-rawa (Nurudin et al. 2013)

Sungai adalah ekosistem akuatik yang berfungsi sebagai penghasilan ikan bagi penduduk disekelilingnya. Sungai terdiri dari komponen abiotik dan biotik yang saling mempengaruhi satu sama lain. Aliran energi mendukung stabilitas ekosistem sungai terbentuk dari integrasi komponen abiotik dan biotik (Purba, 2013).

Kecamatan Rimbo Pengadang, Kabupaten Lebong memiliki yaitu Sungai Sulup. Pembuangan limbah pabrik tempe dan usaha pencucian mobil dan motor serta limbah rumah tangga serta pestisida di sekitar Sungai Sulup dikhawatirkan dapat menyebabkan pencemaran. Hal ini akan mempengaruhi kehidupan organisme yang ada di dalam sungai salah satunya ikan. Sebab Sungai Sulup merupakan salah satu habitat ikan air tawar, dimana ikannya banyak dimanfaatkan oleh penduduk sekitar untuk diambil dan dikonsumsi atau dijual. Selain itu, sungai ini juga merupakan salah satu tempat yang dijadikan mata pencarian oleh penduduk sekitar untuk mencari 
ikan dan digunakan sebagai pengairan atau irigasi persawahan serta pengambilan batu pasir. Adanya limbah di sekitar sungai tersebut dikhawatirkan menurunkan jumlah populasi ikan yang ada. Walaupun penelitian mengenai keanekaragaman ikan sudah banyak dilakukan, namun informasi secara pasti dan akurat mengenai keanekaragaman ikan di Sungai Sulup, Kecamatan Rimbo Pegadang belum terdokumentasi sehingga perlu dilakukan penelitian. Tujuan penelitian ini untuk mengetahui keanekaragaman ikan di Sungai Sulup, Kecamatan Rimbo Pengadang, Kabupaten Rejang Lebong Provinsi Bengkulu.

\section{METODE}

Penelitian ini telah dilaksanakan pada bulan April sampai Mei Tahun 2020 di Sungai Sulup, Kecamatan Rimbo Pengadang Kabupaten Lebong. Kemudian sampel yang didapat diidentifikasi di laboratorium Biologi Universitas Muhammadiyah Bengkulu.

Metode yang digunakan dalam penelitian ini adalah metode survei. Stasiun pengambilan sampel di lapangan ditentukan dengan metode Purposive Sampling dengan cara membagi stasiun penelitian menjadi 3 stasiun, metode ini dipilih karena kondisi jalan menuju sungai tergolong susah dan juga adanya keterbatassan waktu, biaya dan tenaga yang tidak memungkinkan. Adapun pembagian stasiun pengambilan sampel sebagai berikut :

a) Stasiun A (di hulu) : Pada stasiun ini, sungai memiliki karakteristik arus sedang berpasir dan berbatu.

b) Stasiun B (di tengah) : Pada stasiun ini, sungai memiliki karakteristik arus deras berpasir dan berlubuk.

c) Stasiun C (di hilir) : Pada stasiun ini, sungai memiliki karakteristik arus tenang (lubuk).

Sampel diambil dengan menggunakan jala, jaring, bubu, dan pancing. Pengambilan sampel dengan cara acak. Jala digunakan pada kedalaman air kurang dari satu meter. Pancing dan jaring digunakan pada kedalaman air lebih dari satu meter.

\section{Pengukuran Faktor Ekologi}

Pengukuran faktor ekologi dilakukan untuk data pendukung lainya. Adapun faktor yang diamati adalah sebagai berikut :

a. Suhu Air ; Suhu air sungai diukur dengan menggunakan thermometer.

b. Deras Arus

Botol plastik diisi dengan sedikit air, lalu dihanyutkan di permukaan sungai sampai jarak yang di kehendaki. Kemudian hitung berapa waktu yang di butuhkan pada jarak yang telah ditentukan dengan menggunakan stop watch.

$$
\text { Deras Arus }=\frac{\text { Jarak tempuh }}{\text { Waktu Tempuh }}
$$

c. Pengukuran Kejernihan/Kecerahan

Pengukuran kecerahan dilakukan dengan menggunakan alat secchi disk berupa lempengan logam bundar berwarna atau piring yang dicat hitam putih.

d. $\mathrm{pH}$; $\mathrm{pH}$ air diukur dengan $\mathrm{pH}$ indikator. 


\section{Identifikasi Ikan}

Jenis ikan dari hasil penelitian diidentifikasi di Laboratorium Biologi Universitas Muhammadiyah Bengkulu dengan menggunakan buku panduan determinasi Rainboth (1996) dan Kottelat et al. (1993).

\section{Analisis Data}

Analisis data keanekaragaman jenis yang terdapat dalam komunitas menggunakan indeks keanekaragaman dari Shannon-Winner, dengan rumus sebagai berikut:

$$
\begin{aligned}
& \mathrm{H}^{\prime}=-\sum \text { ni/N log ni/N } \\
& \text { Dengan : } \\
& \mathrm{H}^{\prime}=\text { Indeks keanekaragaman Shannon-Winner } \\
& \mathrm{Ni}=\text { Jumlah individu dari satu jenis } \\
& \mathrm{N}=\text { Jumlah total individu seluruh jenis (Samitra \& Rozi, 2018) } \\
& \text { Besarnya indeks keanekaragaman Shannon-Winner sebagai berikut : } \\
& \text { Nilai } \mathrm{H}^{\prime}>3 \quad=\text { keanekaragaman spesies tinggi } \\
& \text { Nilai } \mathrm{H}^{\prime} 1 \leq \mathrm{H}^{\prime} \leq 3=\text { keanekaragaman sedang } \\
& \text { Nilai } \mathrm{H}^{\prime}<1 \quad=\text { keanekaragaman rendah }
\end{aligned}
$$

\section{HASIL DAN PEMBAHASAN}

Berdasarkan hasil penelitian ditemukan 8 spesies ikan yang terdiri dari 4 ordo dan 4 famili (Tabel 1). Ordo Siluriformes terdiri dari 1 famili yaitu Bagridae dan 1 spesies yaitu Mystus singaringan, Ordo Anguilliformes terdiri dari 1 famili yaitu Anguillidae dan 1 spesies yaitu Angullia marmorata, Ordo Cypriniformes terdiri dari 1 famili yaitu Cyprinidae dan 5 spesies yaitu Osteochilus vittatus, Hampala macrolepidota, Barbonymus gonionotus, Schismatorhynchos heterorhynchos dan Rasbora argyrotaenia. Sedangkan ordo Synbranchiformes terdiri dari 1 famili yaitu Mastacembelidae dan 1 spesies yaitu Mastacembelus armatus.

Cyprinidae merupakan family ikan yang paling banyak ditemukan dengan jumlah 5 spesies dibandingankan dengan family Bagridae, Anguilidae dan Mastacembelidae, hal ini karenakan ikan dari family Cyprinidae merupakan ikan yang paling umum dan paling sering ditemukan dihampir semua perairan tawar, khususnya di Sungai Sulup. Hal ini sejalan dengan pendapat Murni et al. (2014) yang menyatakan bahwa Cyprinidae merupakan famili ikan yang sangat umum ditemukan dilingkungan air tawar. Selain memiliki jumlah spesies terbanyak, famili cyprinidae juga mendominasi dari segi Jumlah Individu.

Beberapa hasil penelitian menunjukan di beberapa sungai pulau Sumatra menunjukkan bahwa Cypriniformes terlihat lebih mendominasi jika dibandingkan dengan ordo lainnya (Anwar, 2015; Samitra et al. 2021). Hal ini, dikarenakan jenis Ordo Cypriniformes dominan berhabitat di sungai yang berarus deras dan di lubuk sungai. Sriwidodo et al. (2011) berpendapat dari hasil penelitiannya diperoleh di beberapa sungai di Sumatra Selatan menunjukan bahwa Cypriniformes terlihat lebih mendominasi jika dibandingkan dengan ordo ikan lainnya, dikarenakan sungai di Sumatra Selatan sungai berarus deras dan terdapat bebatuan serta berlubuk. Murni et al. (2014) juga mengemukakan bahwa ikan famili Cyprinidae merupakan penghuni utama yang paling besar jumlah spesiesnya untuk beberapa sungai yang ada di dunia. 
Tabel 1. Jenis ikan di Sungai Sulup Kecamatan Rimbo Pengadang, Kabupaten Lebong, Provinsi Bengkulu

\begin{tabular}{llll}
\hline \multicolumn{1}{c}{ Ordo } & \multicolumn{1}{c}{ Famili } & \multicolumn{1}{c}{ Spesies } & Nama Indonesia \\
\hline Siluriformes & Bagridae & Mystus singaringan & Singgaringan \\
Anguilliformes & Anguillidae & Angullia marmorata & Pelus/Sidat \\
Cypriniformes & Cyprinidae & Osteochilus vittatus & Nilem \\
& & Hampala macrolepidota & Hampala \\
& & Barbonymus gonionotus & Tawes \\
& & Schismatorhynchos heterorhynchos & Cawing hidung \\
Synbranchiformes & Mastacembelidae & Rasbora argyrotaenia & Seluang \\
& & Mastacembelus armatus & Tilan \\
\hline
\end{tabular}

Tabel 2. Jumlah ikan yang diperoleh di Sungai Sulup Kecamatan Rimbo Pengadang Kabupaten Lebong Provinsi Bengkulu

\begin{tabular}{clcccc}
\hline No. & \multicolumn{1}{c}{ Spesies } & \multicolumn{3}{c}{ Stasiun Penelitian } & Jumlah \\
& & Stasiun A & Stasiun B & Stasiun C & \\
\hline 1. & Mystus singaringan & 45 & 12 & 2 & 59 \\
2. & Angullia marmorata & 6 & 1 & 8 & 15 \\
3. & Osteochilus vittatus & 9 & 12 & 7 & 29 \\
4. & Hampala macrolepidota & 10 & 15 & 9 & 34 \\
5. & Barbonymus gonionotus & 10 & 53 & 15 & 78 \\
6. & Schismatorhynchos & 5 & 1 & 9 & 15 \\
& heterorhynchos & & & & \\
7. & Rasbora argyrotaenia & 8 & 12 & 10 & 30 \\
8. & Mastacembelus armatus & 3 & 13 & 15 & 31 \\
\hline & $\quad$ Jumlah & 96 & 119 & 75 & 290 \\
\hline
\end{tabular}

Dari Tabel 2, bahwa ikan yang paling banyak ditemukan di kawasan stasiun B yaitu total individu yang ditemukan adalah 119 individu. Sedangkan di stasiun C hanya sedikit jumlah individu yang di temukan yaitu total individu yang ditemukan adalah 75 individu.

Ikan jenis Barbonymus goinonatus banyak ditemukan di stasiun B, stasiun ini mempunyai karakteristik arus sungai yang deras berpasir dan berlubuk. Ikan tawes (Barbonymus gonionotus) dominan berhabitat di sungai yang berarus deras dan berlubuk, dikarenakan ikan ini mudah mencari makanan yang terdapat di sungai. Hal ini sesuai dengan pendapat Hermasyah (2018) ikan tawes menyenangi perairan yang mengalir deras dan berlubuk, di lingkungan hidupnya ikan tawes memakan tumbuhan hijau seperti daun, rumput dan lumut, ikan tawes merupakan salah satu family dari Cyprinidae yang terkenal paling banyak ditemukan.

Ikan dengan jumlah yang paling sedikit ditemukan yaitu Anguilliformes dengan spesies Angullia marmorata. Pertumbuhan ikan sidat ini tergolong agak lambat dibandingkan pertumbuhan ikan lainnya. Ditambah lagi penangkapan ikan sidat yang berlebihan dengan mengunakan alat seperti pengunaan alat strum ikan dan racun ikan. Aliran sungai sulup sering terjadi pasang surut sehingga hal ini mengakibatkan kelangkaan ikan sidat di perairan Sungai Sulup. Menurunnya jumlah ikan sidat dikarenakan ikan sidat mempunyai daya cerna yang lambat sehingga memiliki pertumbuhan yang lambat (Sagita et al. 2017). Selain itu, pengaruh aktivitas masyarakat menangkap ikan menggunakan alat tangkapan yang tidak ramah lingkungan sehingga terdampak negatif terhadap pertumbuhan ikan sidat di perairan. Hakim et al. (2019) menyatakan bahwa distribusi ikan sidat dipengaruhi oleh kondisi fisik perairan sungai. Ada kemungkinan kondisi fisik yang mempengaruhi yaitu 
arus sungai, Apabila kemiringan dasar sungai rendah, maka pengaruh pasang surut dapat mencapai jauh ke arah daerah hulu, sehingga akan terbawa hingga jauh menuju hulu sungai.

Jumlah ikan yang sedikit ditemukan di Sungai Sulup adalah ikan (pada stasiun C) dimana Stasiun ini memeiliki karakteristik sungai yang berarus tenang (berlubuk), sehingga tidak semua spesies ikan menyenangi karakteristik sungai seperti ini hal ini di sebabkan pada hilir sungai yang merupakan muara memiliki kadar salinitas yang dapat berubah ubah sehingga ikan harus mempunyai toleransi yang tinggi terhadap salinitas yang sering berubah-ubah. Hal ini sependapat dengan (Adjie \& Utomo, 2011) bahwa organisme air seperti ikan di hilir sungai dapat menyesuaikan diri dari karakteristik hilir sungai yang dinamis dipengaruhi pasang surut, terutama kadar salinitas yang berubah-ubah.

Tabel 3. Daftar Indeks Nilai Keragaman Jenis ( $\left.\mathrm{H}^{\prime}\right)$

\begin{tabular}{clcc}
\hline No & Nama Spesies & Jumlah & $\mathrm{H}^{\prime}$ \\
\hline 1. & Mystus singaringan & 59 & 0,140 \\
2. & Angullia marmorata & 15 & 0,066 \\
3. & Osteochilus vittatus & 29 & 0,099 \\
4. & Hampala macrolepidota & 34 & 0,108 \\
5. & Barbonymus gonionotus & 78 & 0,153 \\
6. & Schismatorhynchos heterorhynchos & 15 & 0,066 \\
7. & Rasbora argyrotaenia & 30 & 0,101 \\
8. & Mastacembelus armatus & 31 & 0,103 \\
\hline & Jumlah & 290 & 0,840 \\
\hline
\end{tabular}

Pada Tabel 3, dapat disimpulkan bahwa untuk indeks keanekaragaman ikan di Sungai Sulup, Kecamatan Rimbo Pengadang, Kabupaten Lebong Provinsi Bengkulu sebesar 0,840 dan dikategorikan keanekaragaman rendah. Besar kecilnya nilai indeks keanekaragaman sangat dipengaruhi oleh jumlah individu seluruh spesies yang ditemukan pada masing-masing stasiun. Hal ini dikarenakan sejak 5 tahun terakhir penangkapan ikan dilakukan dengan menggunakan alat strum dan racun ikan, serta masih banyaknya warga yang memanfaatkan sungai sebagai tempat pembuangan limbah rumah tangga, mandi cuci kakus (MCK) dan penangkapan ikan dengan menggunakan alat sentrum dan racun ikan merupakan penyebab utama rendahnya indeks keanekaragaman ikan, hal ini dikarenakan cara penangkapan seperti ini mengakibatkan pemusnahan secara menyeluruh terhadap ikan baik itu benih ikan, induk ikan. Ditambah lagi aktivitas masyarakat yang masih memanfaatkan sungai sebagai tempat MCK sehingga sungai terkontaminasi dengan bahan kimia dari sisa pembuangan air sabun yang di gunakan. Hal ini sesuai pendapat Samitra \& Rozi (2018) rendahnya keanekaragaman disebabkan oleh adanya kegiatan manusia di sekitar yaitu penangkapan ikan dengan menggunakan alat yang tidak ramah lingkungan seperti alat sentrum ikan dan lain-lain, serta masyarakat sekitar menggunakan sungai sebagai tepat Mandi Cuci Kakus (MCK). Faozan (2020) menyatakan bahwa rendahnya keanekaragaman disebabkan oleh adanya penangkapan ikan menggunakan setrum yang dilakukan sebagian oknum masyarakat menyebabkan populasi ikan lokal akan menurun dari tahun ke tahun, karena anak ikan akan ikut mati dan ikan lain juga menghilang.

Dari Tabel 4, diketahui suhu Sungai Air Sulup berkisar pada $21-26{ }^{\circ} \mathrm{C}$, kuat arus air 0,13-0,66 m/s, kedalaman sungai air sulup ini berkisar pada 0,5-4 m, pada tingkat kejernihan ini berkisar diantara $25-100 \mathrm{~cm}$, dan yang terakhir yaitu derajat keasaman $(\mathrm{pH})$ berkisar pada 6,6-7,7. 
Tabel 4. Nilai Pengukuran Parameter Air

\begin{tabular}{clccc}
\hline No. & \multicolumn{1}{c}{ Parameter Air } & Stasiun A & Stasiun B & Stasiun C \\
\hline 1. & Suhu $\left({ }^{\circ} \mathrm{C}\right)$ & 24 & 23 & 23 \\
2. & Kedalaman Sungai (m) & 4 & 1,5 & 3 \\
3. & Kejernihan $(\mathrm{cm})$ & 100 & 45 & 25 \\
4. & pH & 7,7 & 7 & 6,6 \\
5. & Kecepatan arus (m/s) & 0,28 & 0,66 & 0,13 \\
\hline
\end{tabular}

Faktor lain yang mendukung Ordo Cypriniformes banyak ditemukan di setiap stasiun karena Sungai Sulup memiliki suhu air $23^{\circ} \mathrm{C}$, sehingga Sungai Sulup masuk dalam kategori ideal untuk metabolisme dan pertumbuhan organisme perairan di setiap stasiun dan mempunyai Keasaman pH di lokasi penelitian yaitu 7 dan kejernihan $45 \mathrm{~cm}$. Hal ini sesuai dengan pendapat Hamida (2017) faktor lain yang mendukung Ordo Cypriniformes banyak ditemukan di setiap stasiun terdapat faktor lingkungan seperti suhu air yaitu sangat berpengaruh terhadap metabolisme dan pertumbuhan organisme perairan. Suhu air yang ideal hidup antara $22-28^{\circ} \mathrm{C}$. Dan juga sesuai dengan pendapat Wahyuni dan Zakaria (2018) menjelaskan bahwa kondisi perairan sungai sangat mendukung untuk kehidupan ikan yang berada di sungai tersebut dikarenakan kejernihan air sedalam $43 \mathrm{~cm}, \mathrm{pH}$ air sebesar 6,8 dan Suhu air sebesar $24.36^{\circ} \mathrm{C}$, Hal ini menunjukan bahwa suhu tersebut mendukung untuk kehidupan ikan di sungai tersebut.

\section{SIMPULAN}

Hasil Penelitian di Sungai Sulup ditemukan 8 spesies ikan yang terdiri 4 ordo dan 4 famili. Indeks Keanekaragaman sebesar 0,840 yang berkategori rendah.

\section{UCAPAN TERIMA KASIH}

Penulis Ucapkan Terima kasih kepada Universitas Muhammadiyah Bengkulu, Khususnya Lembaga Penelitian dan Pengabdian Masyarakat Universitas Muhammadiyah Bengkulu, serta pihak yang telah membantu yang telah memberikan stimulasi, respon, dan motivasi kepada penulis dalam menulis dan menyelesaikan artikel ini.

\section{REFERENSI}

Adjie, S. \& Utomo, A.J. (2011). Karakteristik Habitat dan Sebaran Jenis Ikan di Sungai Bagian Tengah dan Hilir. Balai Riset Perikanan Perairan Umum dan Penyuluhan Perikanan Palaembang. 3(5), 277-786

Anwar, A., Kardhinata. E.H., \& Mutia H. (2015). Identifikasi Jenis - Jenis Ikan di Sungai Batang Gadis Ecamatan Muarasipongi Kabupaten Mandailing Natal Sumatera Utara. Jurnal BioLink 2(1), 38-46.

Faozan, A. (2020). Penggunaan Alat Tangkap Setrum Ikan Di Sungai Ngrowo Kecamatan Tulungagung Kabupaten Tulungagung. Skripsi IAIN Tulungagung.

Hakim, A. A., Kamel, M. M., Butet, N.A., \& Affandi, R. (2019). Analisis Orde Sungai Dan Distribusi Stadia Sebagai Dasar Penentuan Daerah Perlindungan Ikan Sidat (Anguilla spp.) Di DAS Cimandiri, Jawa Barat. Jurnal Pengelolaan Perikanan Tropis, 3(1), 1-9.

Hamida, A. (2017). Keanekaeragaman Jenis Ikan Di Sungai Enim. Jurnal Iktiologi Indonesia, 4(2), 51-55 
Hermansyah, P. (2018). Keanekaragaman Jenis Ikan Yang Terdapat Di Sungai Air Jernih Kecamatan Padang Guci Hulu Kabupaten Kaur Provinsi Bengkulu. Skripsi FKIP Pendidikan Biologi Universitas Muhammadiyah Bengkulu (Tidak dipublikasikan).

Kottelat, M., J.A Whitten, N, Kartikasari, \&S . Wiryoatmojo. (1993). Freswater Fishes of Wastern Indonesia and Sulawesi. Jakarta: Periplus Edition.

Sriwidodo, E.S., Budiharjo, A., dan Sugiyarto. (2013). Keanekaragaman Jenis Ikan Di Kawasan Inlet Dan Outlet Waduk Gajah Mungkur Wonogiri. Jurnal Bioteknologi 10(2), 43-50

Nurudin, F.A., Martuti, N.K.T., dan Irsadi, A. (2013). Keanekaragaman Jenis Ikan di Sungai Sokenyer Taman Nasional Tanjung Puting Kalimantan Tengah. Jurnal Unnes 2(2), 118-125.

Murni, M.Y., Dahelmi., Roesma, D.I. (2014). Inventarisasi Jenis-Jenis Ikan Cyprinidae di Sungai Batang Nareh Kabupaten Padang Pariaman. Jurnal Biologi Universitas Andalas 3(4), 275-282.

Purba, L. W., Naria, E., Chahaya,. L. (2013). Hubungan Higeine Pengguna Air Sungai Deli Dengan Keluhan Kesehatan Kulit dan Tindakan Pencemaran Sungai di Kelurahan Hamdan Kecamatan Medan Maimun Kota Medan, Jurnal Kesehatan 1(2), 1-8.

Rainboth, W.J. (1996). FAO Species Identification Field Guide For Fishery Purposes. Fishes of The Cambodian Mekong. FAO, Italy.

Sagita, F., Rachmawati, D., \& Suminto. (2017). Pengaruh Penambahan Enzim Papain Pada Pakan Komersial Terhadap Efisiensi Pemanfaatan Pakan, Laju Pertumbuhan Dan Kelulushidupan Ikan Sidat (Anguilla bicolor). Journal of Aquaculture Management and Technology, 6(4), 77-84.

Samitra, D., \& Rozi, Z.F. (2018). Keanekaragaman Ikan di Sungai Kelingi Kota Lubuklinggau. Jurnal Biota, 4(1), 1-6.

Samitra, D., Harmoko, , Sepriyaningsih, Zico F. R., A. Setiawan \& I. Setiawan. (2021). Freshwater fishes of Gegas Dam, South Sumatra Indonesia: composition and diversity. Ecology, Environment and Conservation, 27 (1), 216-221.

Wahyuni, T.W., Zakaria, A., (2018). Keanekaragaman Ikan di Sungai Luk Ulo Kabupaten Kebumen. Jurnal Biosfera, 35(1), 23-28. 